Received : 2019-06-24 Revised : 2019-06-30 Acceptance : 2019-06-30 Publish : 2019-07-22

\title{
THE DESCRIPTION AND THE IMPACT OF PLAYING ONLINE GAME ON PHARMACY STUDENTS IN SAMARINDA
}

\author{
Indah Hairunisa $^{1 *}$, Adinda Shefira Salsabila ${ }^{1}$, Aji Firda Lia Fahrul ${ }^{1}$, Risca \\ Ainun Jariah ${ }^{1}$ \\ ${ }^{1}$ Department of Pharmacy, Faculty of Health and Pharmacy, Universitas Muhammadiyah \\ Kalimantan Timur, Samarinda, Indonesia. \\ Corresponding Author : ih787@umkt.ac.id
}

\begin{abstract}
Online game is a game that can be accessed by the community using internet access. Online games are known to have a fun and addictive effect on their use. Indonesia is the $16^{\text {th }}$ most online game user in the world. This study aims to provide an overview and the impact of the habit of playing online games on Pharmacy students in Samarinda. The method used in this study was using questionnaires distributed to at least 57 respondents of Pharmacy students in Samarinda. The results show that at least $80 \%$ of students have played online games with an average playing time of 1-2 hours in one day. The results of the questionnaire also showed an impact in the form of decreasing students' sensitivity to the surrounding environment and the tendency to speak harshly due to playing online games. Based on the results, it can be concluded that the habit of playing online games can reduce students' sensitivity to their environment and can encourage negative behavior, especially in verbal matters. This research can be used as a preliminary description of behavior changes towards the negative of students due to the habit of playing online games.
\end{abstract}

Keywords :Impact, Online Games, Students, Pharmacy

\section{INTRODUCTION}

This millennial era the advancement of information technology is growing rapidly. One example of technological progress in this era is the internet. Various information can be accessed freely through the internet. Not only information, but entertainment facilities also presented by the internet, for example online games. The first online game that appeared was war simulation games or planes that were used for military purposes which were finally released and then commercialized, these games then inspired other games to emerge and develop. Aside from being a means of entertainment, online games teach something new because of the frequency of frequent play, then someone will imitate the scene in the online game.

Playing online games can have a positive impact, among others, improving the motor system, for example teenagers who play online games can improve play strategy and language skills ${ }^{1}$. In addition to providing a positive impact, online games also have a negative impact especially for gamers, that is, it will be easy to forget the priority scale in their daily activities, for example, causing laziness and addictions. Addiction to online games can trigger destructive actions that harm other people, such as when money runs out to rent a computer or buy a data quota so that they commit acts of theft ${ }^{1}$.

Addiction is a form of behavior that is driven by a high sense of dependence on things he likes so that someone can be said to be addicted if doing the same activities repeatedly can even be more than five times$^{2}$. Individuals who are addicted to online games in a week can spend as much as 30 hours or the 
Received : 2019-06-24 Revised : 2019-06-30 Acceptance : 2019-06-30 Publish : 2019-07-22

average online game addict can spend \pm 20 -25 hours a week, so that in a day they can play for more than 5 hours ${ }^{3}$.

An example of the phenomenon of cases concerning online game addiction that occurred in Indonesia precisely in Banyumas, throughout 2018 ten children in Banyumas were diagnosed with mental disorders due to addiction to playing online games. The Soul Specialist Doctor of Banyumas Hospital, Hilma Paramita, said that the average patient cannot control himself when playing online games. As a result, they are no longer able to move normally ${ }^{4}$.

Based on the explanation above, this research is intended to provide an overview and the impact of playing online games on Pharmacy students in Samarinda. Pharmacy students are chosen on the grounds that the pharmacy major has a fairly high lecture load with more lecture time, practicum and assignments compared to other majors. The high level of lectures will give an idea of whether online games are also played by students with small free time. This research is then expected to be the initial information for parents and teaching staff to be able to find solutions to overcome the habit of playing online games for students.

\section{MATERIAL AND METHOD}

\section{General Procedure}

This research is a quantitative descriptive study with the main objective to explain the existing phenomena by using numbers to rely on individual or group characteristics. This study assesses the nature of the conditions that appear. The purpose of this research is limited to describing the characteristics of something as it is ${ }^{5}$.

This research was conducted by distributing questionnaires using google form to all students of S1 Pharmacy Study Program at the University of Muhammadiyah East Kalimantan (UMKT). Sampling is done by random sampling method for all UMKT pharmacy students. A total of 57 respondents filled out the google form which contained several questions related to the habit of playing online games. The results obtained were then analyzed and grouped and calculated. The questionnaire items used in this study were closed questionnaire items with two until four answer options, where the questions listed were adjusted by the researcher. The alternative answers provided depend on the selection of the researcher and according to the responses of the students who fill. The closed research questionnaire has effective principles when viewed from the researcher's perspective so that the respondent's answers can be adjusted to their needs.

\section{RESULT AND DISCUSSION}

\section{Overview of research respondents}

This research was conducted on second semester students in UMKT Bachelor of Pharmacy study programs using google form. A total of 57 respondents filled out questionnaires. Based on the results obtained, it is known that the distribution of respondents based on sex was obtained as much as $42 \%$ of respondents were male and $58 \%$ of respondents were women. About $98 \%$ of respondents knew about online gaming, and there were only $2 \%$ of respondents who did not know about online games on the grounds that these respondents had never played online games. Based on the data obtained, knowledge about online games is not influenced by gender, this is in accordance with Indonesian gamers' statistical 
data which states that about $56 \%$ of users of online games are male and $44 \%$ of them are women ${ }^{6}$. From these results, it is illustrated that online games can indeed be enjoyed by all sexes without dominating only one gender.

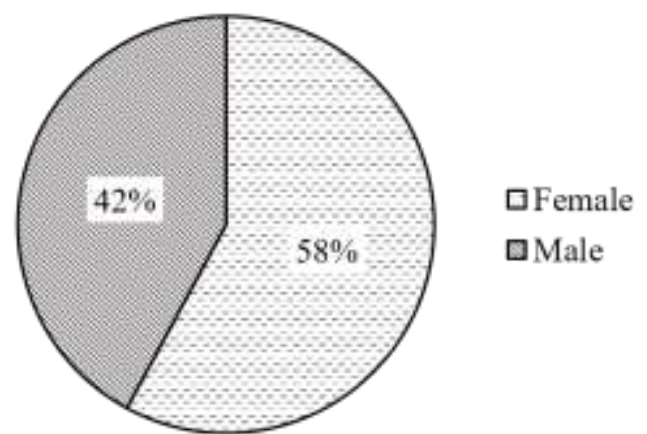

A

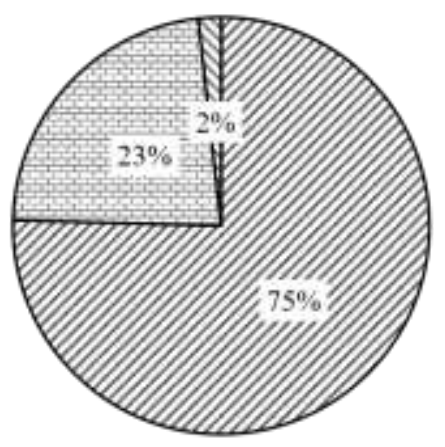

B
๑Know About Game Online

口Little Bit Know About Game Online

QDo Not Know About Game Online

Figure 1. Description of research respondents on UMKT pharmacy students based on sex (A) and knowledge about online games (B).

Based on the results of the questionnaire also stated that there were only $2 \%$ of respondents who did not know about online games, while the other $98 \%$ knew about online gaming. This description of knowledge is in line with the rapid use of the internet by young people. The ease of access and the speed of receiving information seeking through the internet makes student knowledge about online games high. Internet users in Indonesia are estimated at 54\% of indonesian community in 2018, and this figure grew about 143,7 milion from last survey on $2017^{7}$.

\section{Overview of the reasons for driving an online game}

To find out the description of the drivers of UMKT pharmacy students in playing online games, questionnaires were conducted regarding the reasons that were thought to trigger online gaming. Based on the results obtained, the reasons for triggering UMKT pharmacy students to play online games are quite varied and the percentage is not so different. These reasons include boring, hobbies, entertainment and stress with each percentage in a row $28 \%, 21 \%, 19 \%$ and $14 \%$ respectively.

Conducted a study to find out the reason students play online games, based on the results mentioned the main reason students play online games is to eliminate boredom from the learning process at school ${ }^{7}$. But due to the high frequency in playing causes addiction to play. The results of this study also show the tendency of the reason for playing online games is due to boredom, entertainment and stress due to the high lecture process ${ }^{8}$. 
Received : 2019-06-24 Revised : 2019-06-30 Acceptance : 2019-06-30 Publish : 2019-07-22

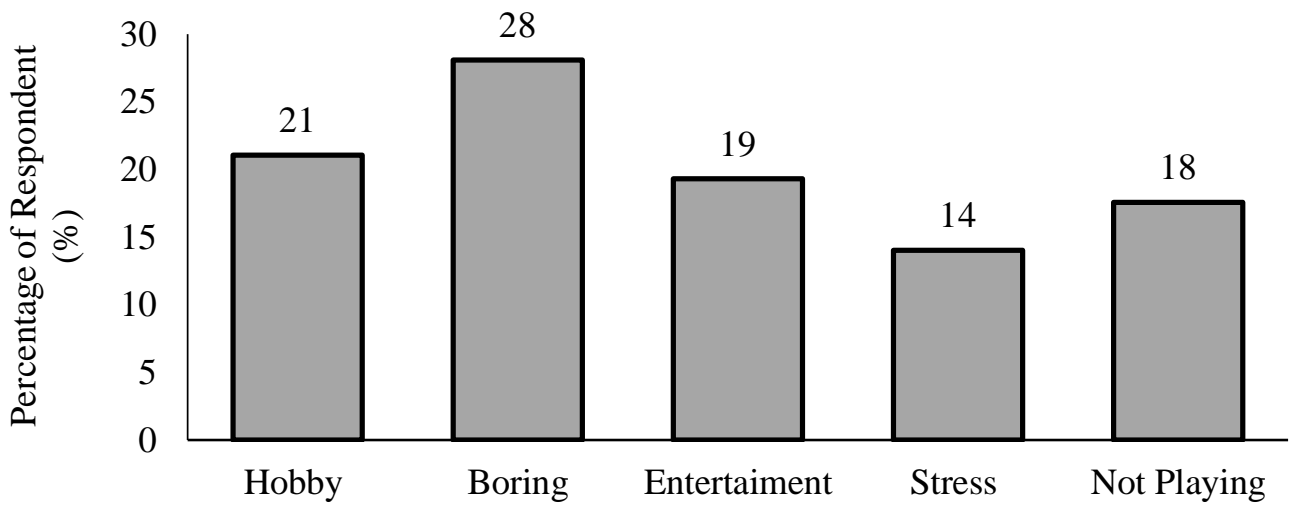

Figure 2. Percentage of motivating reasons for playing online games in pharmacy students at Universitas Muhammadiyah Kalimantan Timur

\section{Overview of the impact and attitude when playing online games}

Basically, both conventional and online games can have a positive or negative impact. This depends on the frequency and duration of someone playing online games. Playing online games can have a positive impact, among others, improving the motor system, for example teenagers who play online games can improve play strategy and language skills ${ }^{1}$. Summarizes at least four domains that accept the positive side of playing online games, namely cognitive (eg, attention), motivational (eg, resilience in the face of failure), emotional (eg, mood management). ), and social (eg, prosocial behavior $)^{8}$.

In addition to providing a positive impact, online games also have a negative impact especially for gamers, that is, it will be easy to forget the priority scale in their daily activities, for example, causing laziness and addictions. At least $97 \%$ of children in the United States use at least 1-2 hours in 1 day to play online games ${ }^{8}$. The results of this study also show similar things, at least $65 \%$ of UMKT pharmacy students use at least 1-2 hours of time playing online games, and $11 \%$ use at least 3-8 hours to play online games in 1 day (figure 3).

Addiction is a form of behavior that is driven by a high sense of dependence on what he likes. A person can be said to be addicted if doing the same activity repeatedly can even be more than five times ${ }^{2}$. Individuals who are addicted to online games in a week can spend as much as 30 hours or the average online game addict can spend \pm 20 -25 hours a week, so that in a day they can play for more than 5 hours ${ }^{1}$. Addiction to online games can lead to destructive actions that harm other people, such as when money runs out to rent a computer or buy a data quota, thus committing acts of theft ${ }^{1}$. Although in the study showed $65 \%$ of respondents spent only 1-2 hours playing online games in a day, $11 \%$ of respondents used at least 3-8 hours to play online games in 1 day. The high percentage in playing online games can still cause the possibility of negative effects from playing online. These negative effects include violence, addiction and even depression ${ }^{9,10,11}$. 
Received : 2019-06-24 Revised : 2019-06-30 Acceptance : 2019-06-30 Publish : 2019-07-22

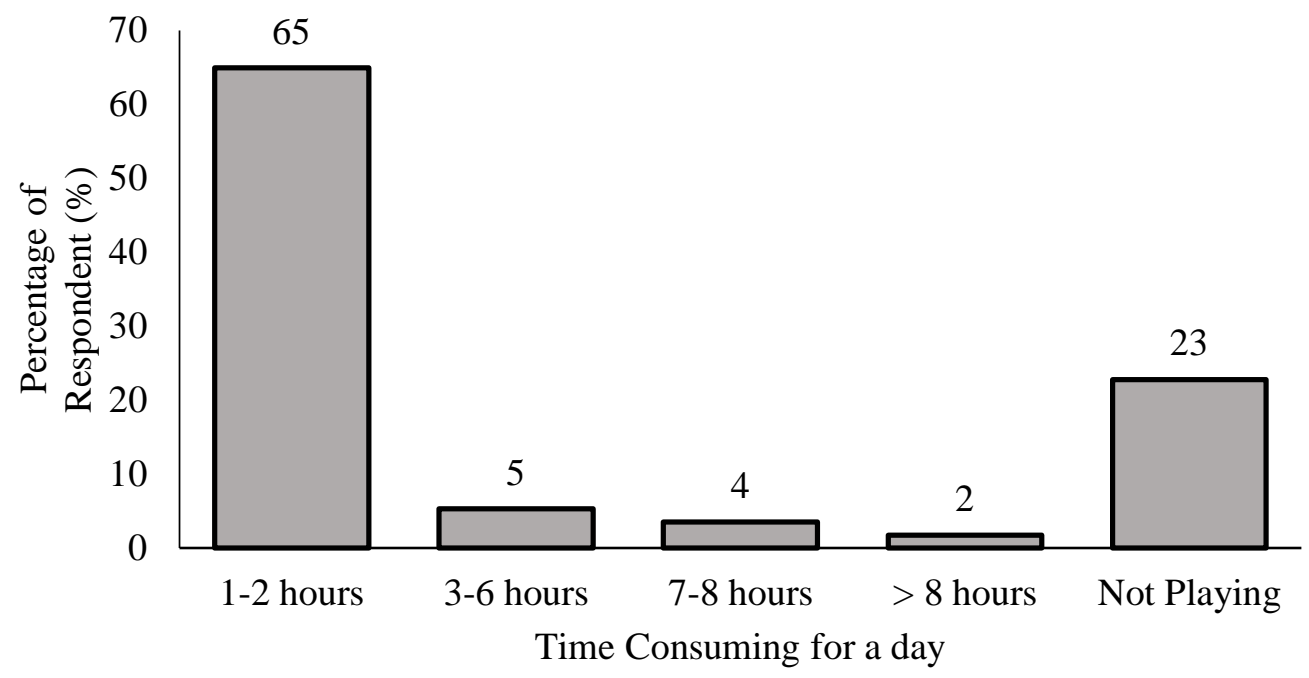

Figure 3. Percentage of time needed to play games in 1 day for pharmacy students at the Universitas Muhammadiyah Kalimantan Timur. The average student uses 1-2 hours to play games for a day.

The tendency to play online games generally can also influence the attitudes of children in their daily lives. This attitude is both in the form of responses to the environment and attitude when playing online games. This study then conducted a survey to describe the attitude of UMKT pharmacy students while playing online games. For students' attitudes towards the environment when they play online games shows $54 \%$ of respondents still give a quick response if asked for help, $23 \%$ delay, $11 \%$ refuse, even $12 \%$ of them feel disturbed. As for attitudes when playing online games, it was found that $39 \%$ of respondents did not say rude, $35 \%$ sometimes said rude, while $26 \%$ were used to saying rude (table 1 ).

Tabel 1. An overview of the attitudes of pharmacy students while playing online games.

\begin{tabular}{|l|c|c|c|}
\hline $\begin{array}{l}\text { Percentage of types of responses given by pharmacy students when requested for assistance } \\
\text { when playing online games }\end{array}$ & Scoring & $\begin{array}{c}\text { Percentage Based } \\
\text { on Scoring }\end{array}$ \\
\hline Type of Responses & Percentage & + & $54 \%$ \\
\hline Quick & $54 \%$ & - & \multirow{2}{*}{$46 \%$} \\
\hline Delay & $23 \%$ & - & Percentage Based \\
Ignorant & $11 \%$ & - & $39 \%$ \\
\hline Upset & $12 \%$ & Scoring & \multirow{2}{*}{$61 \%$} \\
\hline Speak habitof pharmacy students while playing online games & \\
\hline Type of Responses & Percentage & + & - \\
\hline Do not speak harsly & $39 \%$ & - & \\
\hline $\begin{array}{l}\text { Sometimes speak } \\
\text { harsly }\end{array}$ & $35 \%$ & & \\
\hline Speak harsly & $26 \%$ & & \\
\hline
\end{tabular}


Received : 2019-06-24 Revised : 2019-06-30 Acceptance : 2019-06-30 Publish : 2019-07-22

An assessment is made of the respondent's response while playing online games. This assessment was conducted to see the trend of responses from respondents, these trends are negative or positive. By looking at this, the picture of the impact of playing online games will be more visible. The results of the assessment found that $54 \%$ of respondents gave positive responses and $46 \%$ of respondents gave negative responses when asked for help while playing online games. While the respondent's attitude when playing online games was $39 \%$ of respondents did not say rude and positive, while $61 \%$ were negative. The negative scoring on the respondent's attitude on this study contain of "sometimes speak harsly" and "speak harsly". This two answers labelled as negative scoring because this two show the negative attitude of the respondent.

\section{CONCLUSION}

The results show a high percentage of the negative behavior tendency of respondents when playing online games, this trend is even up to more than 50\%. Based on the results obtained, it can be concluded that playing online games can encourage someone to behave negatively, both towards the surrounding environment and be negative when playing the online game.

\section{ACKNOWLEDGEMENT}

This study was funded by Department of Pharmacy, Universitas Muhammadiyah Kalimantan Timur, Indonesia.

\section{REFERENCES}

1. Tridhonanto, A Optimalkan Potensi Anak dengan Game. Jakarta: Elex Media Komputindo. (2011).

2. Cooper, A. Philadelphia: G.H. Buchanan. (2000).

3. Gebrina, A. Bandung: Fakultas Kedokteran Universitas Islam Bandung. (2015).

4. https://www.merdeka.com/peristiwa/kecanduan-game-online-10-anak-di-banyumas-alami gangguan$\underline{\text { mental.html }}$

5. Sugiyono. Metodologi Penelitian Kuantitatif Kualitatif dan $R \&$ D. Bandung: Alfabeta. (2008).

6. https://apjii.or.id/content/read/104/348/BULETIN-APJII-EDISI-22---Maret-2018

7. Eskasasnanda, I, D, P. International Journal of Indonesian Society and Culture. 9 (2) (2017): 191202. doi:10.15294/komunitas.v9i2.9565

8. Granic, I., Lobel,A., and Engels, R.C.M.E. American Psychological Association. Vol. 69, No. 1, 66 78. doi: 10.1037/a0034857

9. Anderson, C. A., Shibuya, A., Ihori, N., Swing, E. L., Bushman, B. J., Sakamoto, A., and Saleem, M. . Psychological Bulletin, 136, 151-173 (2008). doi:10.1037/a0018251

10. Ferguson, C. J., and Olson, C. K. Motivation and Emotion, 37, 154 -164 (2013). doi:1007/s11031012-9284-7

11. Lemola, S., Brand, S., Vogler, N., Perkinson-Gloor, N., Allemand, M., and Grob, A. Personality and Individual Differences, 51, 117-122. (2011). doi:10.1016/j.paid.2011.03.024 